\title{
Reproductive behavior and development in Spilotes sulphureus (Serpentes: Colubridae) from Ecuador
}

\author{
Jorge H. Valencia ${ }^{1}$ and Katty Garzon-Tello ${ }^{1,2}$ \\ ${ }^{1}$ Fundación Herpetológica Gustavo Orcés, Av. Amazonas 3008 y Rumipamba, Casilla 1703448, Quito, Ecuador. \\ E-mail: jorgehvalenciav@yahoo.com. \\ ${ }^{2}$ Vivarium de Quito, Av. Amazonas 3008 y Rumipamba, Casilla 1703448, Quito, Ecuador. E-mail: kattysgarzont@yahoo.com.
}

\begin{abstract}
Reproductive behavior and development in Spilotes sulphureus (Serpentes: Colubridae) from Ecuador. The Birdsnake Spilotes sulphureus is a large-sized species that occurs from the Amazon region to the Atlantic forest of South America. Despite the wide distribution little is known about its natural history. Here we report, for the first time, reproductive behavior displayed by this species observed in a pair of Ecuadorian specimens in captivity. A ritualized pre-copulatory behavior followed a colubrine pattern similar to the congeneric species Spilotes pullatus. The repertoire included chin-rubbing, continuous tongue flicking, head raising, body jerking, cloacal gaping, and partial mounting. Oviposition occurred 86-98 days after of the first copulation. Females lay clutches of 7-14 eggs. Juvenile coloration is remarkably different from adults. Newborns have a dorsum with transverse brown or gray bands, and white or pale gray interspaces; young of 1-2 years have green bands and yellow-green interspaces; adults have dark green bands. Ontogenetic color changes are presumably associated with antipredator strategies, change in size, vulnerability or habitat and microhabitat selection.
\end{abstract}

Keywords: behavior, clutch, development, neonate, reproduction, ontogeny.

\begin{abstract}
Resumen
Comportamiento reproductivo y desarrollo en Spilotes sulphureus (Serpentes: Colubridae) de Ecuador. Spilotes sulphureus es una serpiente de gran tamaño que ocurren desde la región Amazónica hasta el bosques Atlántico de América del Sur. A pesar de su amplia distribución, poco se conoce sobre su historia natural. Nosotros reportamos por primera vez el comportamiento reproductivo presentado por especímenes de Ecuador en condiciones de cautiverio. Un ritual de comportamiento pre-copulatorio fue observado seguido por un modelo colúbrido similar a la especie congenérica como Spilotes pullatus. El repertorio incluye el roce mental, levantamiento de la cabeza, movimientos constantes de la lengua, sacudones del cuerpo, apertura cloacal y monta parcial. El parto ocurre entre 86-98 días después de la primera cópula. Las hembras ponen nidadas de entre 7-14 huevos. Individuos juveniles son notablemente diferentes a los adultos. Los neonatos tienen un dorso con bandas transversales café o grises e interespacios blancos o gris pálidos, individuos de 1-2 años tiene
\end{abstract}

Received 05 February 2018

Accepted 25 May 2018

Distributed June 2018 
bandas verdes e interespacios verde-amarillentos, mientras que los adultos tienen bandas verde oscuras. Cambios ontogénicos están presumiblemente asociados con estrategias anti-depredadoras, cambio de tamaño, vulnerabilidad o selección de hábitats o microhábitats.

Palabras clave: comportamiento, nidadas, desarrollo, neonatos, reproducción, ontogenia.

\begin{abstract}
Resumo
Comportamento reprodutivo e desenvolvimento em Spilotes sulphureus (Serpentes: Colubridae) do Equador. Spilotes sulphureus é uma serpente de grande porte que ocorre desde a região amazônica até as florestas atlânticas da América do Sul. Apesar de sua ampla distribuição, pouco se sabe sobre sua história natural. Relatamos aqui pela primeira vez o comportamento reprodutivo apresentado por indivíduos do Equador em condições de cativeiro. Um ritual de comportamento pré-copulatório foi observado seguido por um modelo colubrídeo similar ao de Spilotes pullatus. O repertório de comportamentos inclui o roçar da região do mento, o levantamento da cabeça, movimentos constantes da língua, vibrações do corpo, abertura cloacal e cobertura parcial da fêmea. A desova ocorre entre 86-98 dias após a primeira cópula. As fêmeas depositam ninhadas de 7-14 ovos. Os indivíduos juvenis são notavelmente diferentes dos adultos. Os neonatos possuem o dorso dotado de faixas transversais cor de café ou cinzentas e separadas por espaços brancos ou cinza-claros, os indivíduos de 1-2 anos têm faixas verdes separadas por espaços verde-amarelados e os adultos exibem faixas verde-escuras. Mudanças ontogenéticas estão presumivelmente associadas a estratégias de defesa contra predadores, mudanças de tamanho, vulnerabilidade ou seleção de hábitats ou micro-hábitats.
\end{abstract}

Palavras-chave: corte, neonatos, ninhadas, ontogenia, reprodução, serpentes.

\section{Introduction}

The Neotropical Birdsnakes and Puffing Snakes comprises large-sized snakes of the genera Spilotes Wagler, 1830 and Phrynonax Cope, 1862, with five recognized species: Phrynonax polylepis (Peters, 1867), P. poecilonotus (Günther, 1858), P. shropshirei (Barbour and Amaral, 1924), Spilotes pullatus (Linnaeus, 1758), and S. sulphureus (Wagler, 1824), and two apparently undescribed species from Central America and Brazil (Jadin et al. 2013). Spilotes sulphureus is widely distributed through northern South America and some Caribbean islands and it is among the largest Neotropical colubrid snakes (Peters and Orejas-Miranda 1970, Duellman 1978, Dixon and Soini 1986, PérezSantos and Moreno 1991). In Ecuador, $S$. sulphureus occurs in the provinces of Sucumbíos, Morona Santiago, Orellana, Napo, and Pastaza (Pérez-Santos and Moreno 1991, OrtegaAndrade 2010). Knowledge of the natural history of this species is limited to anecdotal notes on microhabitats or prey species (e.g., Beebe 1946, Cunha and Nascimento 1978, Duellman 1978, Rivas and Kane 2003). Reproductive biology and behavior are also poorly known.

At Vivarium de Quito, Ecuador in 2009, a long-term study was initiated to study reproductive biology and behavior in Ecuadorian snakes. The aim is to determine behavior patterns, duration of copulation and pregnancy, clutch size, parturition, hatching time, ontogeny, and development. Herein, techniques for husbandry and reproduction are described, and behavior related to reproductive biology and development is reported for $S$. sulphureus.

\section{Material and Methods}

\section{Animal and Site Ecological Data Collection}

Adults of Spilotes sulphureus were collected from two different localities. The female (FHGOv 2603) is $2340 \mathrm{~mm}$ in total length and weighs $950 \mathrm{~g}$. It was collected at 14:00 h on 26 
April 2003 at Tipishca $\left(00^{\circ} 12^{\prime}\right.$ S, $76^{\circ} 12^{\prime} \mathrm{W} ; 242$ $\mathrm{m}$ a.s.1.), Cuyabeno Faunistic Reserve, province of Sucumbíos (Figure 1); a protected area of 655,781 ha, where four forest types are found: "Igapo" forest flooded by black water rivers and lakes, "Cananguchal" forest flooded by white water from small rivers, a form of varzea seasonally flooded forest, and terra firme forest (Vitt and De la Torre 1996, Sierra 1999, Ministerio de Ambiente del Ecuador 2012). The

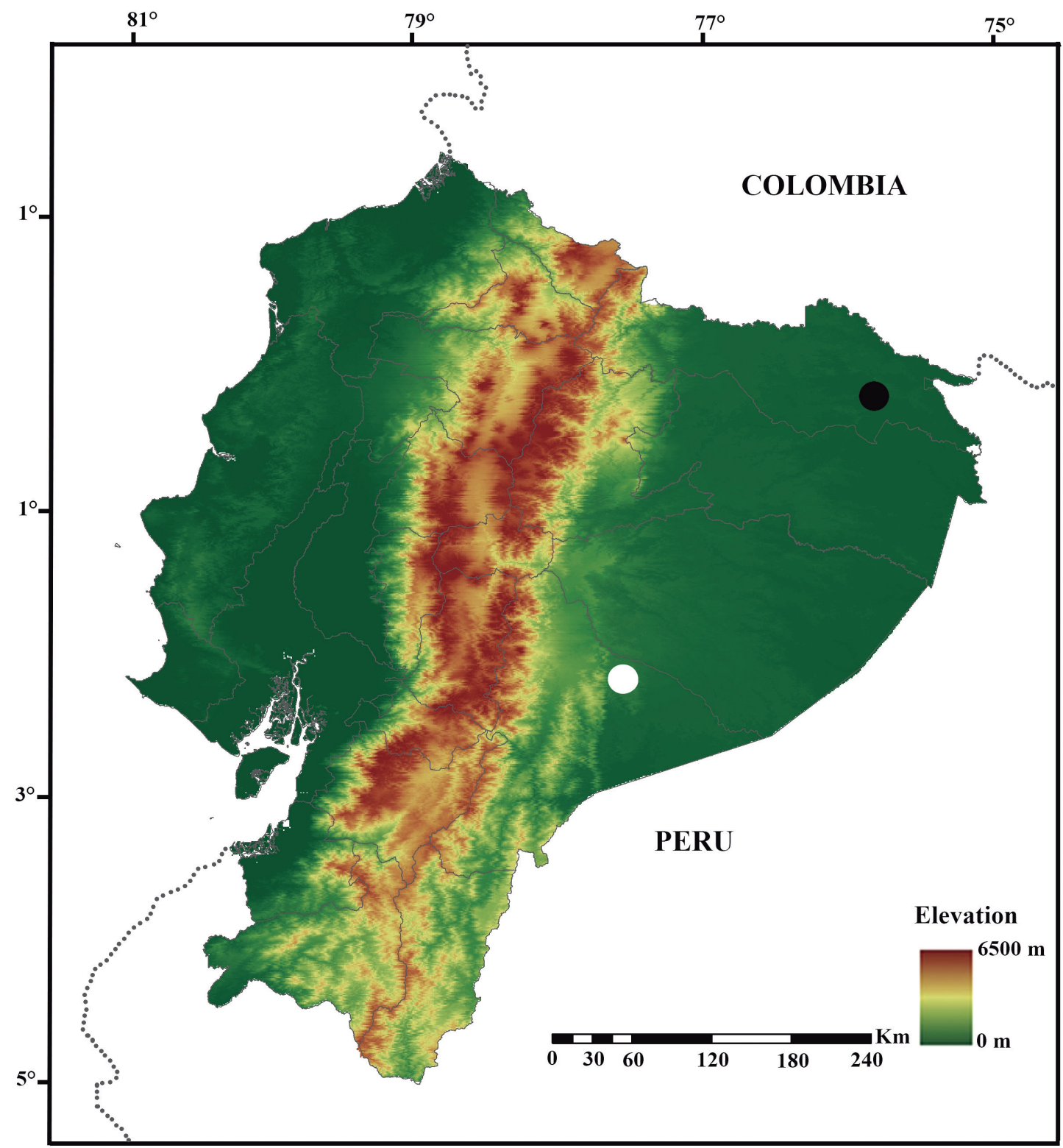

Figure 1. Map of Ecuador showing the localities of Tipishca, province of Sucumbíos (black circle) and Paantim, province of Morona Santiago (white circle) where female and male were collected. 
male (FHGOv 2492) is $2320 \mathrm{~mm}$ in total length and weighs $1800 \mathrm{~g}$. It was collected on 02 July 2001 at Paantim $\left(02^{\circ} 08^{\prime} 39^{\prime \prime} \mathrm{S}, 7^{\circ} 42^{\prime} 03^{\prime \prime} \mathrm{W} ; 631\right.$ $\mathrm{m}$ a.s.1.), province of Morona Santiago (Figure 1), a locality characterized by lowland rainforest and pre-montane rainforest near the lower part of Cordillera del Cutucu (Borgtoft et al. 1998).

\section{Laboratory Maintenance}

Both adults were housed at Vivarium de Quito (FHGOv), under similar conditions. Initially, adults were individually maintained in fiberglass terrariums, under controlled environmental conditions (temperature $23-25^{\circ} \mathrm{C}$, humidity $70-75 \%$ ). The terraria were rectangular cages $(100 \mathrm{~cm} \times 80 \mathrm{~cm} \times 100 \mathrm{~cm}$ high), with sliding glass door, and floor covered by rough paper.

The snakes were given chlorine-free water ad libitum and fed small chicks or quail once per week. They were exposed to ambient light cycles; the daily cycle was 12 hours (06:00 18:00 h). Additional humidity was provided by manual irrigation by a 10-liter sprinkler in the terraria with chlorine-free water once per day. The specimens were maintained in these terraria for a quarantine period of 60 days. Following this quarantine, they were individually housed in cages of glass and wood, $150 \mathrm{~cm} \times 100 \mathrm{~cm} \times$ $200 \mathrm{~cm}$ high.

On 6 August 2010, the snakes were placed together in a breeding terrarium. This terrarium was a large cage of glass and wood, $150 \mathrm{~cm} \times$ $100 \mathrm{~cm} \times 200 \mathrm{~cm}$ high, with northern exposure. An artificial circular pond (diameter $70 \mathrm{~cm}$, depth $50 \mathrm{~cm}$ ) was filled with chlorine-free water. A fluorescent lamp over the terrarium provided UVB light on a cycle of 12 hours. Automatic irrigation was provided for five minutes twice per day (between 09:30-19:30 h). The floor was covered with a peat moss substrate (Stender® No. 610), predominantly consisting of dead, humified plant material. Substrate temperature was maintained using electric plate heaters at $25-27^{\circ} \mathrm{C}$ and relative humidity was $65-75 \%$ measured with thermometer and hygrometer NatCare ${ }^{\circledR}$. The breeding terrarium contained bromeliad plants (Guzmania Ruiz \& Pav. or Tillandsia L.), branches, stones, and a ceramic cave (diameter $65 \mathrm{~cm} \times 30 \mathrm{~cm}$ high) for shelter. Human access to the breeding terrarium was limited to feeding and weekly cleaning.

Following oviposition, eggs were removed from the breeding terrarium, and individually marked, weighed using a digital balance, and measured with digital caliper. Eggs were then placed together in a plastic cage $(30 \mathrm{~cm} \times 20 \mathrm{~cm}$ $\times 15 \mathrm{~cm}$ high), and covered with humid peat moss substrate for incubation purposes. The substrate was manually sprayed with chlorinefree water daily.

Neonates were measured using a metal ruler, weighed using a digital balance and maintained individually in plastic cages $(50 \mathrm{~cm} \times 30 \mathrm{~cm} \times$ $25 \mathrm{~cm}$ high), with an artificial perch, water bowl and floor covered by rough paper. Eggs' and neonates' containers were maintained under controlled conditions (stable humidity and temperature), and monitored daily. Snout-vent length (SVL) and mass of neonates were measured monthly for one year after hatching. Any hatchlings that died were preserved in alcohol and deposited in the collection of FHGO.

\section{Data Collection}

General observations on reproductive repertoire were carried out from August to November 2009, and development and growth of eggs and young from November 2010 to March 2012. A Canon DCR-DVD 201 video camera was used to record the activity of the snakes during day and night. Recordings of five seconds length were made each minute; the videos were later analyzed. In addition, data on each specimen were entered on an activity record sheet each hour. Juveniles specimens were measured ( $\mathrm{mm}$ ) and weighed monthly (g). Animal housing and handling procedures, as well as the experimental protocols involving captive animals were approved by the Biodiversity Department, 
Ministerio del Ambiente, Ecuador. Research permits were issued by Ministerio del Ambiente, Ecuador, through the wildlife management patent $\mathrm{N}^{\mathrm{o}}$ 2011-11-FAU-DPAP-MA, and $\mathrm{N}^{\mathrm{o}}$ 2012-09-FAU-DPAP-MA.

\section{Statistical Analysis}

Relative clutch mass (RCM) was calculated following Vitt and Congdon (1978): RCM = CM / FTM, where CM = clutch mass and FTM $=$ female total mass including clutch mass. Snout-vent length (SVL) and mass increase in male and female neonates were compared using a one-way analysis of variance (ANOVA). We used a Shapiro-Wilk test to examine normality of residuals and a Tukey's HSD test was used to determine pairwise differences, if applicable. ANOVA and other tests were conducted in Past version 3.07 (Hammer et al. 2001) with alpha level set at 0.05. Dispersion around means is indicated by $+/$ - one standard error unless otherwise indicated.

\section{Results}

We recognized five phases of the reproductive behaviour of Spilotes sulphureus: recognition; courtship; copulation; pregnancy and oviposition, which we describe below. We also describe the hatchling phase and ontogeny of the young as post-breeding phases. The results are presented sequentially.

\section{Recognition}

On 6 August 2010, both snakes were housed together in the breeding terrarium for the first time (Figure 2). They actively investigate the cage and each other, contacting their bodies several times in the process (Figure 3A), but without head contact, and with unusual periodic tongue-flicking. The male was constantly active, whereas the female rested periodically. The recognition process lasted approximately five hours. Expulsion of fecal matter was observed

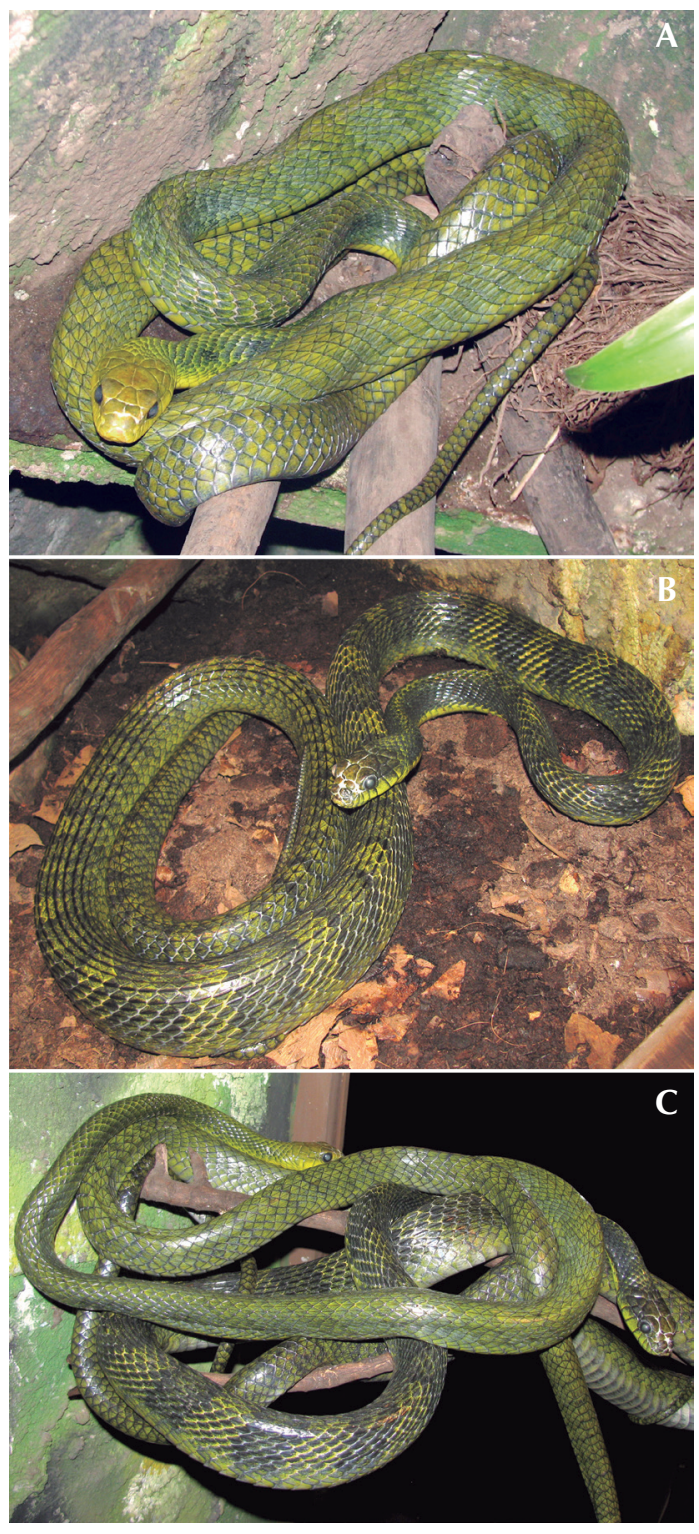

Figure 2. (A) Adult male (FHGOv 2492) and (B) female (FHGOv 2603) of Spilotes sulphureus included in this study; $(\mathbf{C})$ both adults resting together in the post-recognition phase.

during this phase. Then, the male climbed to the highest branch $(\sim 1.5 \mathrm{~m}$ above the floor), while the female remained on the substrate; both were coiled indicating a resting period. During the 

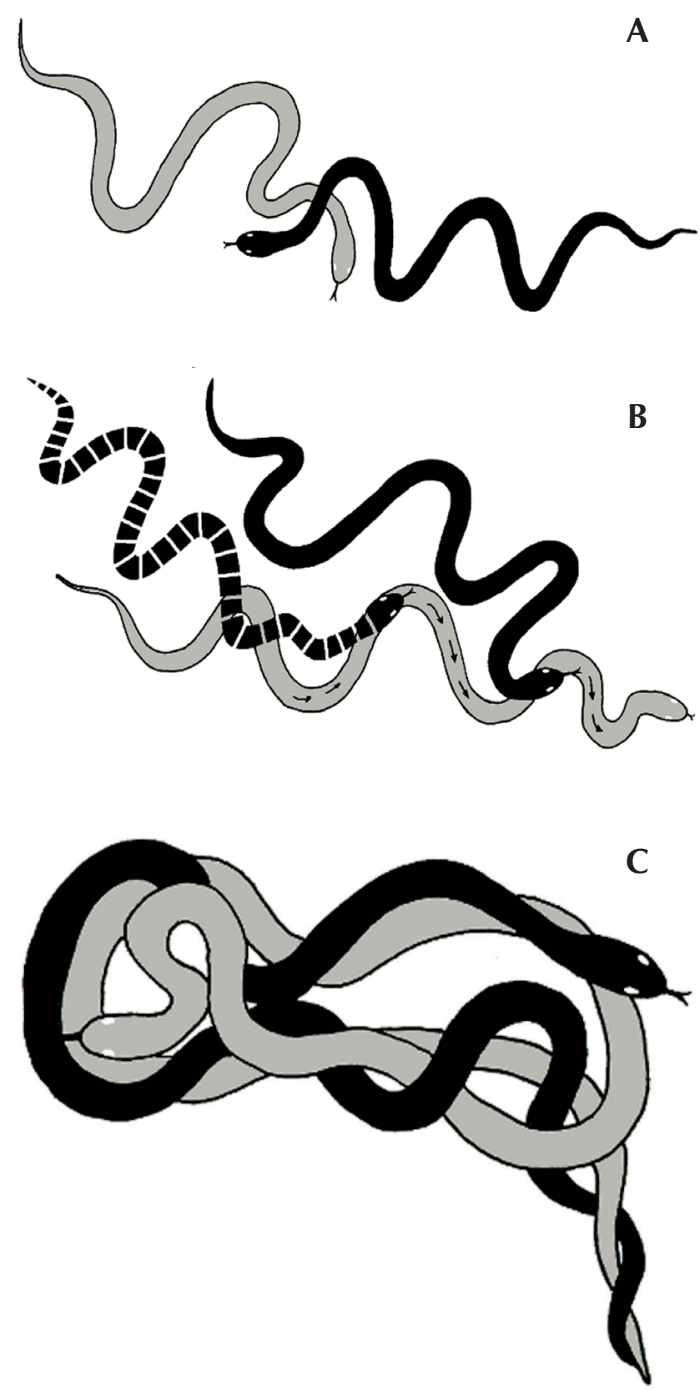

Figure 3. Reproductive repertoire in Spilotes sulphureus: (A) recognition phase: male (black) and female (gray) contacting their bodies occasionally; this phase occurs on the ground; (B) courtship phase: movement of male on the female dorsum, initial contact (black and white) by rubbing his chin along of the female dorsum, followed by movement towards the head (black); this phase occurs on the ground; $(\mathbf{C})$ copulation phase: male and female coiled together, their tails are intertwined and hanging, this phase occurs on the perch. next two days the male and female remained together, resting and coiled in the same area, until the copula day.

\section{Courtship}

Courtship or tactile-chase occurred on 08 August 2010. At 09:00 h, courtship begins with the male tongue-flicking the dorsal integument of the female. The male also made continuous circular movements around the female. The female exhibited a short ( $10 \mathrm{~s})$ display of head-jerking behavior, and rapid tongueflicking, while the male exhibited short ( $20 \mathrm{~s})$ consecutive dilations of the throat. A sequence of male tongue-flicking was observed at 11, 13, 20, 23 and $25 \mathrm{~min}$ during the courtship, each tongue-flicking lasting 5-12 s; the female responded with small body jerks of the anterior body. The male intermittently rubbed his chin along the female's dorsum, but not the female's head (Figure 3B). Dorsal contractions in both individuals were also observed during this phase.

\section{Copulation}

The first copulation occurred on the same day as courtship (08 August 2010) and six additional copulations were observed over the next three weeks, the last one on 28 August 2010. Copulation occurred every $2-4$ days, and had an average duration of $12 \mathrm{~min}$. In this phase, male and female were coiled together on a branch $1.5 \mathrm{~m}$ above the substrate. Prior to copulation, the heads of the snakes were not in contact, and the tails hung below the perch, slightly entangled (Figure 3C). The male then intromitted one of his hemipenes into the female's gaped cloaca. The female's body contracted 5-8 times per minute, frequently with the throat inflated. During copulation, the male and female remain motionless except for periodic tongue flicking. No copulatory plugs were deposited into the female's cloaca at the termination of copulation. In a post-copulatory 
process, the male retracted the hemipenis and both snakes crawled slowly away from each other and coiled on the branch.

\section{Pregnancy}

Duration of pregnancy was 98 days. The female ate regularly, taking three quails and seven chicks. No shedding or pre-shedding process was observed for the female during this phase. In the latter stages of pregnancy (13 days) the female would often coil tightly in the place where she later deposited eggs, on the substrate. During the last two weeks of pregnancy, the female was more active, making erratic movements on the perch. If disturbed, she quickly assumed the typical defensive posture, raising the anterior body in S-shape and inflating the throat. Two hours prior to oviposition, the female appeared restless and crawled continuously around the enclosure. She also exhibited a rippling motion of the posterior body, accompanied by the expulsion of fecal matter.

\section{Oviposition}

Oviposition occurred on 07 November 2010, 98 days after the first copulation, at about 16:00 h. During this phase, female coiled on a perch $0.60 \mathrm{~m}$ above the substrate, the anterior third of the body in a vertical plane with the head slightly inclined towards the coiled body. The cloaca was positioned horizontally and slightly raised, until the first egg appeared (Figure 4A). At this time the posterior part of the body was lowered vertically, the cloaca $80 \mathrm{~cm}$ above the substrate (Figure 4B). Eggs were deposited on the ground at intervals of about five minutes; the entire oviposition process required approximately 60 min. At the beginning of oviposition, the male was resting on a perch $1.5 \mathrm{~m}$ above ground, at a distance of $\sim 0.80 \mathrm{~m}$ from the female. After the oviposition of the fourth egg, the male coiled on the substrate $\sim 30 \mathrm{~cm}$ from the eggs, with periodic tongue-flicking (Figure 4C). After depositing six eggs from the perch, the female descended to the substrate. She deposited five eggs in rapid succession; these eggs adhered together. A cloacal discharge was observed following the last egg (Figure 4D).

\section{Eggs and Hatching}

Immediately after oviposition, the female coiled around the clutch of 11 moist, soft, ovoid eggs (Figure 4B-C) staying tightly coiled for about three hours. Then the female moved to one side, coiling up next to the eggs and rubbing some of them with part of her body. When the eggs were removed from the terrarium, the female showed defensive behavior, raising the anterior body in S-shape and inflating the throat, and constantly rubbing some of the eggs. The female also made strong and repeated jerks with the side of body in contact with the eggs when they were taken. Furthermore, the female made several strikes (mouth open) at the hands of the staff who removed the eggs.

Measurements and weight of the eggs are: length 60.5-78.8 mm, mean $66.4 \mathrm{~mm}, \mathrm{SD}=$ \pm 5.1; diameter $27.8-39.2 \mathrm{~mm}$, mean $30.8 \mathrm{~mm}$, $\mathrm{SD}= \pm 3.5$; weight 5.9-7.3 g, mean $6.7 \mathrm{~g}, \mathrm{SD}=$ $\pm 0.4 ; \mathrm{RCM}=0.087$ (Table 1 ). The eggs were placed in the plastic cage with peat moss after measurement. Two eggs were removed after 77 days of incubation because mold and collapse of the egg wall indicated spoilage. One egg was pipped after 85 days, but contained a dead, welldeveloped hatchling. The remaining eight eggs were manually opened at 98 days to ensure the survival of the hatchlings. Two eggs had completely collapsed and were stained dark brown, two other contained well-developed dead hatchlings. The remaining six hatchlings were in excellent condition (Figure 5A-B).

\section{Hatchling, Ontogeny, and Development}

By 22 January 2011, six young (one male and five females) had hatched. Egg tooth marks on the eggshells were not observed. Measure- 


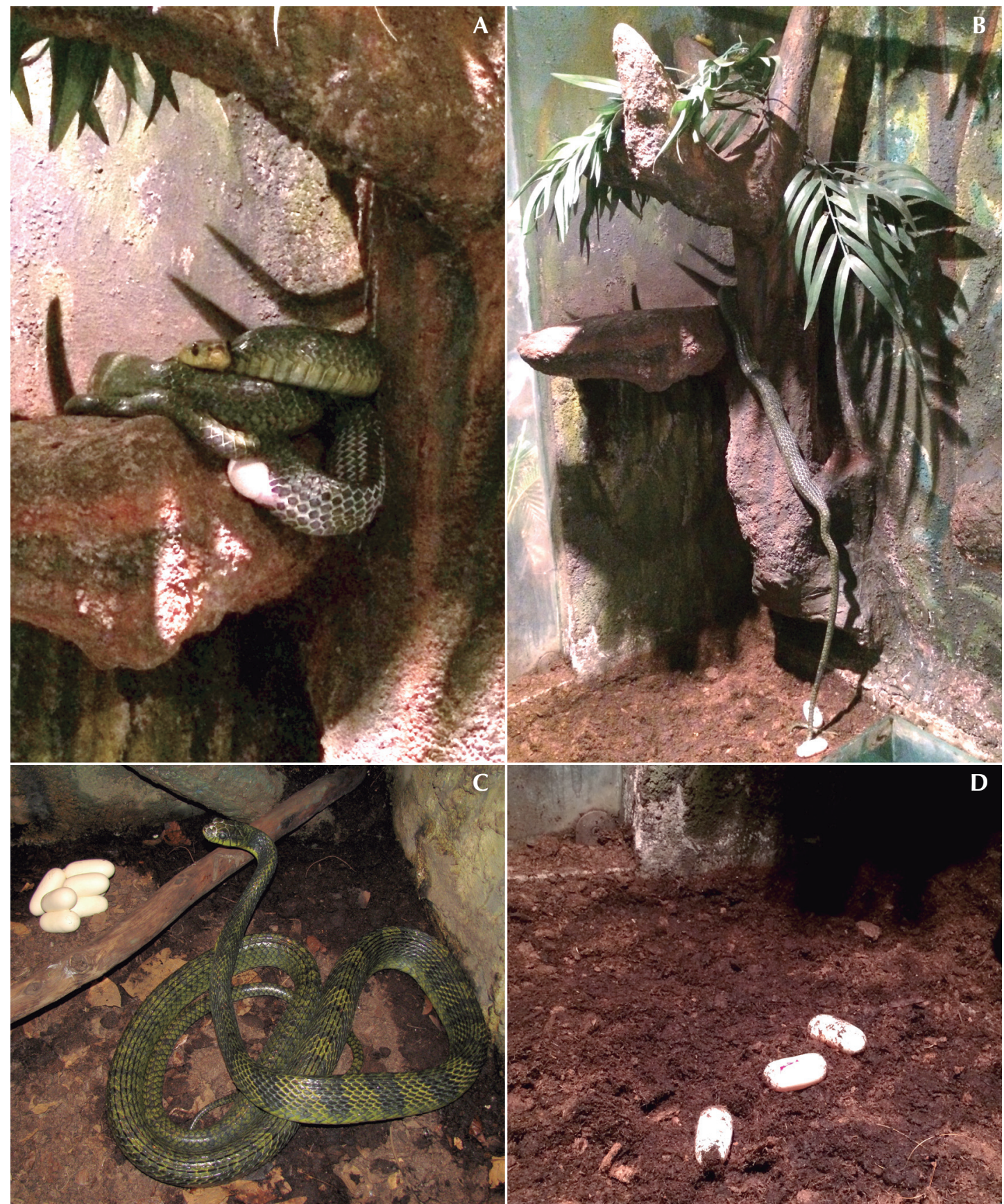

Figure 4. Gravid female of the Spilotes sulphureus in the oviposition phase: (A) gravid female coiled on the perch with cloacal opening showing the first egg; (B) gravid female laying the second egg from the perch; (C) active male in the parturition phase near second group of eggs; (D) three eggs of the first group laid on the ground. 

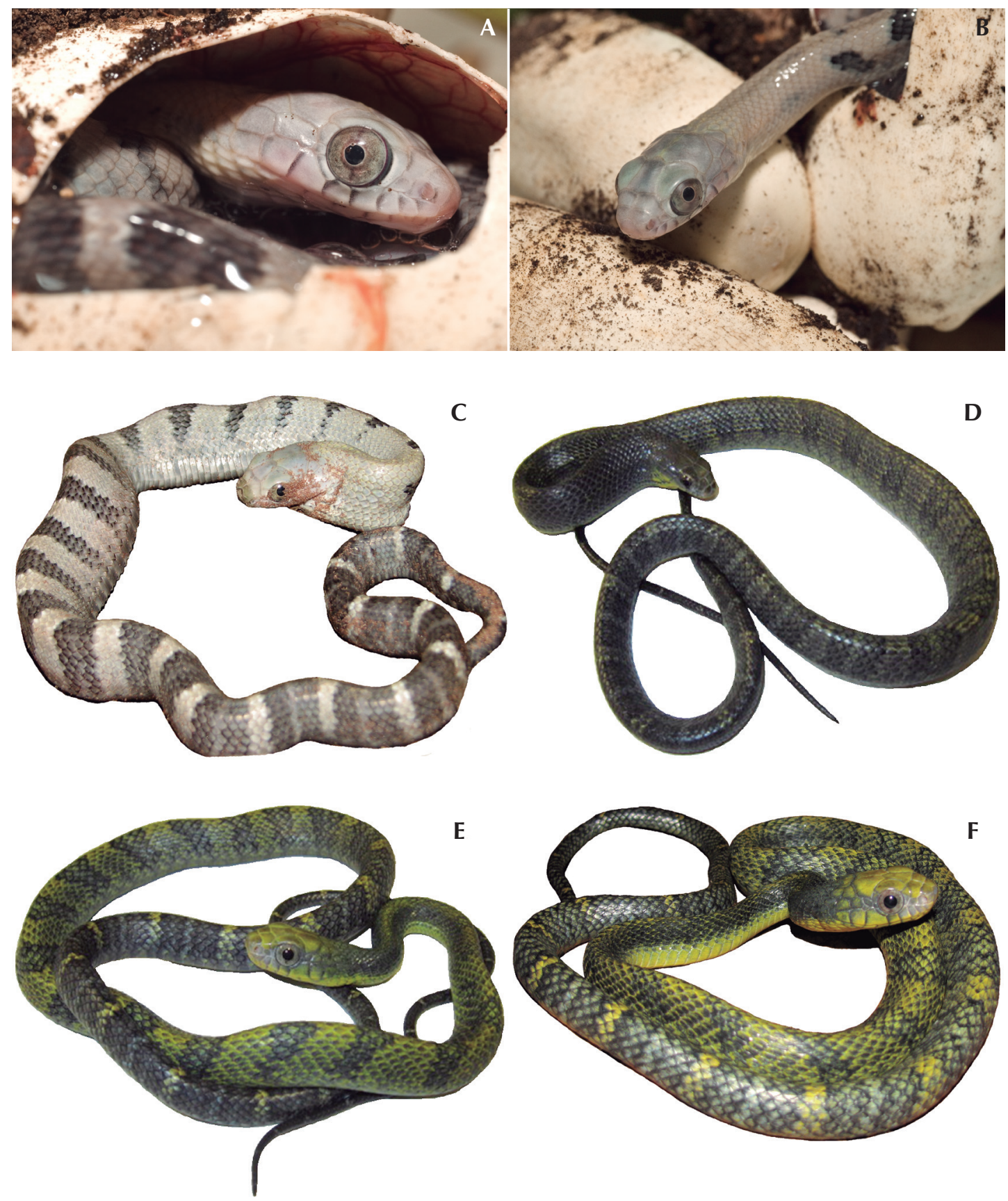

Figure 5. Development in neonates Spilotes sulphureus: (A-B) pipped egg with fully formed live young; (C) neonate with typical gray and cream dorsal coloration; (D) three-month-old juvenile with gray and green dorsal color pattern; juveniles of six (E) and twelve (F) months of age with yellow and green dorsal coloration. 
Table 1. Measurements and incubation time for eleven Spilotes sulphureus eggs.

\begin{tabular}{lccccc}
\hline Eggs & $\begin{array}{c}\text { Length } \\
(\mathbf{m m})\end{array}$ & $\begin{array}{c}\text { Diameter } \\
(\mathbf{m m})\end{array}$ & $\begin{array}{c}\text { Weight } \\
(\mathbf{g})\end{array}$ & $\begin{array}{c}\text { Incubation } \\
\text { time (days) }\end{array}$ & Comments \\
\hline 1 & 60.8 & 27.9 & 6.8 & 98 & Fully formed and alive \\
2 & 69.8 & 29.3 & 7.3 & 98 & Fully formed and alive \\
3 & 66.8 & 32.8 & 6.9 & 77 & Collapsed \\
4 & 66.0 & 29.0 & 6 & 98 & Pipped, opened and fully formed, but dead \\
5 & 78.8 & 31.8 & 6.2 & 77 & Collapsed \\
6 & 67.4 & 39.2 & 6.8 & 98 & Fully formed and alive \\
7 & 65.3 & 28.6 & 7 & 98 & Fully formed and alive \\
8 & 66.4 & 30.9 & 5.9 & 98 & Pipped, opened and fully formed, but dead \\
9 & 71.1 & 35.5 & 7 & 98 & Fully formed and alive \\
10 & 62.3 & 29.3 & 6.6 & 98 & Fully formed and alive \\
11 & 60.5 & 27.8 & 6.9 & 85 & Pipped, opened and fully formed but dead \\
\hline
\end{tabular}

ments and weight of the hatchlings one day after births are: snout-vent length (SVL) 420 $671 \mathrm{~mm}$, mean $595.5 \mathrm{~mm}, \mathrm{SD}= \pm 91.5$; weight 15-30 g, mean $21.2 \mathrm{~g}, \mathrm{SD}= \pm 6.6$. SVL of the females was greater than SVL of the male (Table 2). The first shed occurred 10-12 days after hatching, and the second shed took place 11-14 days after the first shed. No food was offered prior to the first shedding. After the first shed, neonates were offered live laboratory mice, weighing $35-45 \%$ of the snakes' mass, but the food was refused. Two days later, they were offered rain frogs, Pristimantis unistrigatus (Günther, 1859), weighing 10$15 \%$ of the snakes' masses; these were accepted. At the second feeding, six days after the first, the hatchlings accepted live laboratory mice. The hatchlings were fed mice at approximately six day intervals. The females grew faster than the male. Mean SVL was significantly greater in females than in the male $(F=4.28, d f=1, p=0.044$; Shapiro-Wilk test, $\mathrm{P}=0.98)$. Mean mass was also significantly different among females and male $(F=1,473$, $d f=1, p=0.23$; Shapiro-Wilk test, $\mathrm{P}=0.81$ ). Overall, mean values of SVL and weight in females are greater than the male (Turkey's HSD test, $\mathrm{P}=0.04$ ).

The juveniles showed an ontogenetic shift in dorsal color pattern. Initially, the dorsum was pale gray with well-defined dark gray bands. The dorsal pattern changed after the second shed; dorsum of body and head was pale green; the body bands dark green. Ten months later, the dorsum became yellowish green with dark green bands; these bands do not extend across the venter on the anterior third of body. Fifteen months after hatching, dorsal bands are poorly defined or absent on the anterior third, usually appearing green suffused with yellow (Figure $5 \mathrm{C}-\mathrm{F})$.

\section{Discussion}

The knowledge of the reproductive processes in snakes is underrepresented, despite their rich variation in mating behavior, male-male combat, and sexual size dimorphism (Shine 1993, Senter et al. 2014). The few data, field and experimental records, come from limited taxonomic groups such as North American natricines (e.g. Blanchard and Blanchard 1942, Barry et al. 
Table 2. Sex, mass and snout-vent length (SVL) for six Spilotes sulphureus hatchlings recorded monthly over the course of a year.

\begin{tabular}{|c|c|c|c|c|c|c|c|c|c|c|c|c|c|c|}
\hline Individual & Sex & Measurements & J & $\mathbf{F}$ & $\mathbf{M}$ & A & $M$ & J & J & A & $\mathbf{S}$ & $\mathbf{O}$ & $\mathbf{N}$ & D \\
\hline \multirow{2}{*}{1} & \multirow{2}{*}{ Female } & Mass (g) & 30 & 32 & 37 & 40 & 41 & 45 & 47 & 53 & 55 & 59 & 63 & 66 \\
\hline & & $\mathrm{SVL}(\mathrm{mm})$ & 642 & 663 & 710 & 744 & 757 & 791 & 802 & 839 & 889 & 927 & 986 & 1060 \\
\hline \multirow{2}{*}{2} & \multirow{2}{*}{ Female } & Mass (g) & 25 & 28 & 29 & 31 & 31 & 33 & 35 & 39 & 40 & 41 & 42 & 47 \\
\hline & & $\mathrm{SVL}(\mathrm{mm})$ & 671 & 670 & 690 & 701 & 723 & 740 & 798 & 810 & 844 & 900 & 1009 & 1022 \\
\hline \multirow{2}{*}{3} & \multirow{2}{*}{ Female } & Mass (g) & 16 & 17 & 19 & 21 & 21 & 21 & 22 & 24 & 26 & 29 & 30 & 33 \\
\hline & & $\mathrm{SVL}(\mathrm{mm})$ & 605 & 633 & 690 & 699 & 705 & 710 & 738 & 790 & 810 & 840 & 899 & 905 \\
\hline \multirow{2}{*}{4} & \multirow{2}{*}{ Female } & Mass (g) & 15 & 15 & 16 & 16 & 16 & 18 & 20 & 21 & 24 & 27 & 27 & 31 \\
\hline & & $\mathrm{SVL}(\mathrm{mm})$ & 585 & 641 & 664 & 689 & 691 & 699 & 721 & 745 & 797 & 831 & 856 & 888 \\
\hline \multirow{2}{*}{5} & \multirow{2}{*}{ Female } & Mass (g) & 26 & 27 & 29 & 31 & 32 & 33 & 35 & 40 & 45 & 50 & 55 & 61 \\
\hline & & $\mathrm{SVL}(\mathrm{mm})$ & 650 & 693 & 712 & 733 & 742 & 758 & 776 & 799 & 829 & 843 & 890 & 944 \\
\hline \multirow{2}{*}{6} & \multirow{2}{*}{ Male } & Mass (g) & 15 & 15 & 16 & 17 & 17 & 17 & 19 & 20 & 22 & 24 & 27 & 29 \\
\hline & & $\mathrm{SVL}(\mathrm{mm})$ & 420 & 550 & 580 & 620 & 633 & 644 & 689 & 724 & 769 & 784 & 800 & 824 \\
\hline
\end{tabular}

1992, Aldridge 2001, Brown and Weatherhead 1999a, b) and more recently in some Neotropical boids (Pizzato et al. 2006), colubrids (AlmeidaSantos and Marques 2002, Sasa and Curtis 2006, Marques et al. 2009, Pinto et al. 2010, Munizda-Silva and Almeida-Santos 2013, Rojas et al. 2013), elapids (Missasi et al. 2017) and pitvipers (Almeida-Santos and Salomão 2002). Due to the secretive nature of the great majority of snakes, these records are often anecdotal or restricted to limited distribution range or laboratory tests usually focused on few species.

Reproductive repertoire has been recorded for only 6\% of snake species (Schuett et al. 2001, Muniz-da-Silva and Almeida-Santos 2013). Senter et al. (2014) proposed a series of behavioral characters associated with colubrines, the majority of which occur in Spilotes sulphureus. This species exhibited the most conspicuous courtship characters observed in other colubrine snakes: chin-rubbing, coiling, cloacal contact, tail entanglement, head raising, jerking, and partial mounting, but pre-coital or coital neck bites and alignment of bodies were not observed.
The mating behavior of $S$. sulphureus in this study occurred in August during the rainy season. The mating period for $S$. pullatus occurs from August to October suggesting that they share the same mating seasons (Marques et al. 2014).

Although we did not observe male-male combat in Spilotes sulphureus, it was observed in S. pullatus (Muniz-da-Silva and AlmeidaSantos 2013), and the related snakes Chironius bicarinatus (Wied-Neuwied, 1820) and $C$. flavolineatus (Jan, 1863) (Almeida-Santos and Marques 2002, Marques et al. 2009, Pinto et al. 2010).

Goode (1989) reported clutches of 7 and 14 eggs in Spilotes sulphureus. Of the latter clutch, seven eggs hatched 84-86 days after deposition. Our clutch of 12 eggs hatched 98 days after copulation. Santos-Costa et al. (2015) report offspring of S. sulphureus in February, March, and December. Martins and Oliveira (1988) suggested that hatching in S. sulphureus may occur during most of the year in the Manaus region, Brazil. 
The litter size (LS) of 12 eggs and relative clutch mass (RCM) 0.087 of Spilotes sulphureus in this study appear low compared to other large snake species: Chrionius bicarinatus (LS = 5-14; $\mathrm{RCM}=0.55, \quad N=1)$, Chironius quadricarinatus (Boie, 1827) $(\mathrm{LS}=6-7, \mathrm{RCM}=$ $0.43, N=2$ ), and Spilotes pullatus (LS $=5-14$, RCM $=0.31-0.48, N=17$ ) (Amaral 1929, Marques et al. 2009, Pinto et al. 2010, Marques et al. 2014).

Our results showed a $50 \%$ hatching success rate, similar to that of Goode (1989). Hatching success is probably related to incubation conditions (Gutzke and Packard 1987, Burger et al. 1987, Andrews 2008, Packard and Packard 1988, Werner and Shine 2008).

The hatching process itself is a critical event; many embryos are unable to cut the egg shell while others die during hatching (Burger et al. 1987). Many young reptiles cut the egg shell with an egg tooth, a structure on the premaxillary bone prior to emergence (Anan'eva and Orlov 2013). Although we did not find marks on the egg shells in this study, we found two prominences on the premaxillary bone of dead neonates that do not occur in adults, suggesting that these structures may be used to break the egg shells.

Ontogenetic color pattern changes were observed in S. sulphureus. These are presumably adaptive and associated with antipredator strategies, changes in size, vulnerability or habitat and microhabitat selection (Booth 1990) but their functional significance is poorly understood. Adults of $S$. sulphureus feed mostly on arboreal prey (Duellman 1978, Rufino and Bernardi 1999, Rivas and Kane 2003; Fraga et al. 2013), while juveniles consume ground-dwelling lizards, amphisbaenians, and small rodents (Fraga et al. 2013). This may be the reason for the ontogenetic changes in color pattern.

\section{Acknowledgments}

We are indebted to María Elena BarragánPaladines for permission to work at the laboratories of Vivarium de Quito. Miguel Alcoser-Villagómez, Diego Chungandro, Soledad Estupiñan, Diana Herrera, Dwain Holmes, and Pablo Picerno maintained the specimens and recorded numerous behavioral observations. Pete Oxford, Diego Chungandro and M. Alcoser-Villagómez photographed some of the reproductive behavior and hatching events. Jaime Bosch, Enrique Caldeira-Costa, Ross MacCulloch, and two anonymous reviewers made useful comments that improved significantly this manuscript. Diego Morillo and Gabriela Montoya (MAE) helped with technical and administrative support. This research was supported by Vivarium de Quito, Fundación Herpetológica Gustavo Orcés.

\section{References}

Amaral, A. 1929. Estudos sobre ophidios neotrópicos, XIX. Revisão do gênero Spilotes Wagler, 1830. Memórias do Instituto Butantan 4: 275-298.

Aldridge, R. D. 2001. Reproductive anatomy, mating season, and cost of reproduction in the glossy snake (Arizona elegans). Amphibia-Reptilia 22: 243-249.

Almeida-Santos, S. M. and O. A. V. Marques. 2002. Malemale ritual combat in the colubrid snake Chironius bicarinatus from the Atlantic Forest, southeastern Brazil. Amphibia-Reptilia 23: 528-533.

Almeida-Santos, S. M. and M. G. Salomão. 2002. Reproduction in Neotropical pitvipers, with emphasis on species of the genus Bothrops. Pp. 445-462 in G. W. Schuett, M. Höggren, M. E. Douglas, H. W. Greene (eds.), Biology of the Vipers. Carmel. Eagle Mountain Press.

Anan'eva, N. B. and N. L. Orlov. 2013. Egg teeth of Squamata reptiles and their phylogenetic significance. Biology Bulletin 40: 1351-1357.

Andrews, R. M. 2008. Effects of incubation temperature on growth and performance of the veiled chameleon (Chamaeleo calyptratus). Journal of Experimental Zoology 390: 435-446.

Barry, F. E., P. J. Weatherhead, and D. P. Phillip. 1992. Multiple paternity in a wild population of northern water snake, Nerodia sipedon. Behavioral Ecology and Sociobiology 30: 193-199. 
Beebe, W. 1946. Field notes on the snakes of Kartabo, British Guiana, and Caripito, Venezuela. Zoologica 31: $11-52$.

Blanchard, F. N. and F. C. Blanchard. 1942. Mating of garter snakes Thamnophis sirtalis sirtalis (Linnaeus). Papers of the Michigan Academy of Science, Arts, and Literature 27: 215-234.

Borgtoft, H., F. Skov, J. Fjeldså, I. Schjellerup, and B. Ǿllgaard. 1998. People and Biodiversity. Two Cases Studies from the Andean Foothills of Ecuador. Copenhagen. Centre for Research on the Cultural and Biological Diversity of the Andean Rainforest, DIVA. $190 \mathrm{pp}$.

Booth, C. L. 1990. Evolutionary significance of ontogenetic colour change in animals. Biological Journal of Linnean Society 40: 125-163.

Brown, G. P. and P. J. Weatherhead. 1999a. Demography and sexual size dimorphism in northern water snakes, Nerodia sipedon. Canadian Journal of Zoology 77: $1358-1366$.

Brown, G. P. and P. J. Weatherhead. 1999b. Female distribution affects mate searching and sexual selection in male northern water snakes (Nerodia sipedon). Behavioral Ecology and Sociobiology 47: 9-16.

Burger, J., R. T. Zappalorti, and M. Gochfeld. 1987. Developmental effects of incubation temperature on hatchling pine snakes Pituophis melanoleucus. Comparative Biochemical Physiology 87A: 727-732.

Cunha, O. R. and F. P. Nascimento. 1978. Ofídios da Amazônia. X. As cobras da região leste do Pará. Papéis Avulsos do Museu Paraense Emilio Goeldi, Zoologia 31: $2-18$.

Dixon, J. R. and P. Soini. 1986. The reptiles of the upper Amazon basin, Iquitos region, Peru. II. Crocodilians, turtles and snakes. Contributions in Biology and Geology, Milwaukee Public Museum 12: 1-71.

Duellman, W. E. 1978. The biology of the Equatorial herpetofauna in Amazonian of Ecuador. Miscellaneous Publications of the Museum of Natural History, University of Kansas 65: 1-352.

Fraga, R., A. P. Lima, A. L. C. Prudente and W. E. Magnusson. 2013. Guide to the Snakes of the Manaus Region, Central Amazonia. Manaus. Editoria INPA. 303 pp.

Goode, M. 1989. Pseustes sulphureus. Reproduction. Herpetological Review 20: 73.

Gutzke, W. H. N. and G. C. Packard. 1987. Influence of the hydric and thermal environments on eggs and hatchlings of bull snakes Pituophis melanoleucus. Physiological Zoology 60: 9-17.

Hammer, Ø., D. A. T. Harper, and P. D. Ryan. 2001. PAST: paleontological statistics software package for education and data analysis. Paleontologia Electronica 4: $1-9$.

Jadin, R. C., F. T. Burbrink, G. A. Rivas, L. J. Vitt, C. L. Barrio-Amorós, and R. P. Guralnick 2013. Finding arboreal snakes in an evolutionary tree: phylogenetic placement and systematic revision of the Neotropical birdsnakes. Journal of Zoological Systematics and Evolutionary Research 52: 1-6.

Ministerio del Ambiente del Ecuador. 2012. Sistema de Clasificación de los Ecosistemas del Ecuador Continental. Proyecto Mapa de Vegetación del Ecuador. Quito. Subsecretaria de Patrimonio Natural, Ministerio del Ambiente del Ecuador. 138 pp.

Marques, O. A. V., S. M. Almeida-Santos, M. G. Rodrigues, and R. Camargo. 2009. Mating and reproductive cycle in the Neotropical colubrid snake Chironius bicarinatus. South American Journal of Herpetology 4: 76-80.

Marques, O. A. V., D. F. Muniz-Da-Silva, F. E. Barbo, S. R. T. Cardoso, D. C. Maia, and S. M. Almeida-Santos. 2014. Ecology of the colubrid snake Spilotes pullatus from the Atlantic Forest of southeastern Brazil. Herpetologica 70: 407-416.

Martins, M. and M. E. Oliveira. 1998. Natural history of snakes in forest of the Manaus region, central Amazonia, Brazil. Herpetological Natural History 6: 78-150.

Missasi, A. F. R., R. Z. Coeti, V. J. Germano, and S. M. Almeida-Santos. 2017. Micrurus lemniscatus carvalhoi (Coralsnake). Reproduction. Male-male combat. Herpetological Review 48: 214-215.

Muniz-Da Silva, D. F. and S. M. Almeida-Santos. 2013. Male-male ritual in Spilotes pullatus (Serpentes: Colubridae). Herpetological Bulletin 126: 25-29.

Ortega-Andrade, H. M. 2010. Diversidad de la herpetofauna en la Centro Amazonía del Ecuador. Unpublished M.Sc. Dissertation. Instituto de Ecología, D. C. Xalapa, México.

Packard, G. C. and M. J. Packard. 1988. The physiological ecology of reptilian eggs and embryos. Pp. 523-606 in C. Gans and R. B. Huey (eds.), Biology of the Reptilia. Volume 16B. New York. Academic Press.

Pérez-Santos, C. and A. G. Moreno. 1991. Serpientes de Ecuador. Monografie di Museo Regionale di Scienze Naturali 11: 1-539. 
Peters, J. A. and B. Orejas-Miranda. 1970. Catalogue of Neotropical Squamata: part I. Snakes. Bulletin of the United States National Museum 297: 1-347.

Pinto, R. R., O. A. V. Marques, and R. Fernandes. 2010. Reproductive Biology of two sympatric colubrid snakes, Chironius flavolineatus and Chironius quadricarinatus, from the Brazilian Cerrado domain. Amphibia-Reptilia 31: 463-473.

Pizzato, L., R. H. Manfio, and S. M. Almeida-Santos. 2006. Male-male ritualized combat in the Brazilian rainbow boa, Epicrates cenchria crassus. Herpetological Bulletin 95: $16-20$.

Rivas, J. A. and S. Kane. 2003. Pseustes sulphureus (Amazon Puffing Snake). Diet. Herpetological Review 34: 72.

Rojas, C. A, V. A. Barros, and S. M. Almeida-Santos. 2013. The reproductive cycle of the male sleep snake Sibynomorphus mikanii (Schegel, 1837) from southeastern Brazil. Journal of Morphology 274: 215-228.

Rufino, N. and J. A. R. Bernardi. 1999. Pseustes sulphureus sulphureus. Diet. Herpetological Review 30: 103-104.

Santos-Costa, M. C., G. F. Maschio, and A. L. C. Prudente. 2015. Natural history of snakes from Floresta Nacional de Caxiuanã, eastern Amazonia, Brazil. Herpetology Notes 8: 69-98.

Sasa, M. and S. Curtis. 2006. Field observations of mating behavior in the neck-banded snake Scaphiodontophis annulatus (Serpentes: Colubridae). Revista de Biología Tropical 54: 647-650.
Schuett, G. W, E. W. A. Gergus, and F. Kraus. 2001. Phylogenetic correlations between male-male fighting and mode prey subjugation in snakes. Acta Ethologica 4: $31-49$.

Senter, P., S. M. Harris, and D. L. Kent. 2014. Phylogeny of courtship and male-male combat behavior in snakes. PloS ONE 9: e107528.

Shine, R. 1993. Sexual dimorphism in snakes. Pp. 49-86 in R. A. Seigel and J. T. Collins (eds.), Snakes: Ecology and Behavior. New York. McGraw-Hill.

Sierra, R. 1999. Propuesta Preliminar de Un Sistema de Clasificación de Vegetación para El Ecuador Continental. Quito. Proyecto INEFAN/GEF-BIRF y EcoCiencia. 174 pp.

Vitt, L. J. and J. D. Congdon. 1978. Body shape, reproductive effort, and relative clutch mass in lizards: resolution of a paradox. American Naturalist 112: 595-608.

Vitt, L. J. and S. De la Torre. 1996. A Research Guide to the Lizards of Cuyabeno. Quito. Centro de Biodiversidad y Ambiente, Pontificia Universidad Católica del Ecuador. $165 \mathrm{pp}$.

Werner, D. A. and R. Shine. 2008. The adaptive significance of temperature-dependent sex determination in a reptile. Nature 451: 566-568.

Editor: Ross D. MacCulloch 